doi:10.1016/j.scitotenv.2005.04.008

Copyright (c) 2005 Elsevier B.V. All rights reserved.

\title{
Validation of the exposure assessment for veterinary medicinal products
}

\section{Mark H.M.M. Montforts}

National Institute of Public Health and the Environment (RIVM) PO box 13720 BA Bilthoven, The Netherlands

* Tel.: +31 302742529; fax: +31302744401.

\begin{abstract}
Under the EU Directive 2004/28/EC, an environmental risk assessment of new veterinary medicinal products is required. Given the nature of risk assessment for new applications, there is a need to model exposure concentrations. Critical evaluations are essential to ensure that the use of models by regulators does not result in the propagation of misleading information. The empirical validations of soil exposure models, previously discussed in this journal, indicate that it is impossible to analyse the contribution of every model parameter to the variability in the predictions. In particular, the prediction of the slurry concentration is challenged by uncertainties concerning dilution, mixing and dissipation of residues. Surface water and groundwater models generated highly deviating results compared to the field results, questioning the usefulness of the available screening models. Animal husbandry, slurry handling and environmental conditions throughout Europe are considered in order to define realistic worst case scenarios, to be used in conjunction with distribution models for the environmental risk assessment of veterinary medicinal products at registration. Given the variability in manure management practice throughout Europe, a deterministic approach for the manure-to-soil model was selected. Both worst case and best case scenario were developed. Several modelling assumptions applied in the surface water exposure model for fish nursery effluent were validated against newly available data. Since the available data give no proof that a settling tank contributes to the removal of pesticides from waste water, it is recommended for risk assessment purposes to consider the contribution of the settling tank to removal of pesticides and medicines to be negligible. Surface water dilution factors may be considered to be rather small, a factor of 2 , for low flow situations.
\end{abstract}

\section{Introduction}

The marketing of veterinary medicinal products is actively regulated in the European Union (EU) by Directive 2001/82/EC, amended by Directive 2004/28/EC, in order to protect the environment, next to animal health, consumers and professional users. An environmental risk assessment is to be performed at registration and there is a clear policy and regulatory infrastructure to deal with this issue, as well as a number of regulatory guidance documents on the environmental risk assessment (EMEA, 1997, DG Enterprise, 2000, VICH, 2000 and $\mathrm{VICH}, 2003$ ). Given the nature of risk assessment for new applications, where monitoring data are lacking, there is a need to model exposure concentrations and associated risks. All models are, by their nature, incomplete representations of the system they are intended to model. The regulatory goals of model predictions are diverse and three groups of models are discerned based on their applicability: screening, primary and secondary models (FOCUS, 1995). The first objective of this paper is to validate existing screening level exposure models for the risk assessment of veterinary medicines spread in manure that have been presented previously in this journal by Montforts et al. (1999). Addiscot et al. (1995) stated that some form of critical evaluation procedure is essential to maintain the integrity of modelling and to ensure that the use of models by regulators does not result in the propagation of misleading information. Validation is used here in the meaning of establishing whether the model is 'well founded and applicable' (Addiscot and Wagenet, 1985, Dee, 1995 and Addiscot et al., 1995). Screening level models do not intend to represent reality accurately, but to provide rapid 
predictions of the potential environmental fate of a compound (Tarazona et al., 2003). To validate this claim, the available screening models are compared in Section 2 to field data published in literature for soil, surface water and groundwater (Hamscher et al., 2000, Hamscher et al., 2002, Winckler and Grafe, 2001b, Boxall et al., 2002, Schlüsener et al., 2003, Aga et al., 2003 and De Liguoro et al., 2003).

A second objective of this paper is to develop scenarios for the risk assessment under different European conditions. These scenarios should incorporate information on realistic agricultural and veterinarian practice, land use, geomorphology and climate. The objective of the scenarios, in combination with screening models, presented in Section 3 is to function as screening tools in the European registration procedures for veterinary medicines.

Finally, a third objective pursued in section four is the verification of the $50 \%$ removal factor, the dilution factor and the emission pattern, assumed for the exposure assessment of the use of medicines in fish nurseries by Montforts et al. (1999).

The results of the validation exercise are discussed in section five with a view to develop a consistent risk model for the registration of veterinary medicines in the EU.

\section{Screening model validation}

\subsection{Empirical validation of the soil exposure models}

Soil exposure screening models for veterinary medicines have been proposed and discussed in literature (Boxall et al., 1997, Spaepen et al., 1997, Jorgensen et al., 1998, Montforts et al., 1999, WRc-NSF, 2001 and Kelly et al., 2003). These deterministic and functional models for local exposure concentrations have been applied for other environmental contaminants such as heavy metals, pathogens and biocides (Breimer and Smilde, 1986, Montfoort et al., 1996, Walker and Stedinger, 1999 and Van der Poel and Bakker, 2002). The modelling of regional distributions, applied for nutrients or pathogens in manure, was generally not used for registration of chemicals (Walker, 1997, Walker et al., 1998, Walker and Stedinger, 1999, Vega et al., 2001 and Menzi, 2002). The exception to the rule is the VetPec model designed for screening assessments in the UK at the registration of veterinary medicines (WRc-NSF, 2001).

The soil exposure models at the screening level describe the concentration of the excreted residue in the slurry and the concentration of the residue in soil after application of the slurry. The elementary deterministic soil concentration model used for veterinary medicines is described by:

$$
\begin{aligned}
& Q_{\text {excreted }}=Q_{\text {product }} \cdot C_{c} \cdot T_{\text {treatment }} \cdot F_{\text {excreted }} \cdot m_{\text {animal }} \cdot \text { Ncyclus animal } \\
& C_{\text {slurry }}=\frac{Q_{\text {excreed }}}{P_{\text {slury }}} \cdot \mathrm{e}^{-h \text { deg shryy }} \cdot T_{\text {surage }} \\
& \text { PECsoil }=\frac{C_{\text {slury }} \cdot Q_{\text {slury }}}{\rho_{\text {soil }} \cdot \mathrm{CONV}_{\text {area field }} \cdot \text { DEPTHfield }}
\end{aligned}
$$

with the following explanation of symbols (Table 1). 
Science of The Total Environment Volume 358, Issues 1-3 , 1 April 2006, Pages 121-136

Table 1.

Explanation of symbols for the soil concentration model

\begin{tabular}{|c|c|c|}
\hline \multicolumn{3}{|l|}{ Input } \\
\hline$Q_{\text {product }}$ & dosage product used & {$\left[\mathrm{kg} \mathrm{kg}_{\mathrm{bw}}{ }^{-1}\right.$ day $\left.^{-1}\right]$} \\
\hline$C_{\mathrm{c}}$ & concentration chemical (c) in product & {$\left[\mathrm{mg}_{\mathrm{c}} \mathrm{kg}^{-1}\right]$} \\
\hline$T_{\text {treatment }}$ & duration of treatment & [days] \\
\hline$m_{\text {animal }}$ & (averaged) body weight & {$\left[\mathrm{kg}_{\mathrm{bw}}\right.$ animal $\left.^{-1}\right]$} \\
\hline$F_{\text {excreted }}$ & fraction excreted in faeces and urine & \\
\hline Ncyclus $_{\text {animal }}$ & number of cycli per year & {$\left[\right.$ animal place ${ }^{-1}$ year $^{-1}$ ] } \\
\hline$P_{\text {slurry }}$ & slurry production animal in stable in 1 year & {$\left[\mathrm{kg} \mathrm{place}^{-1}\right.$ year $\left.^{-1}\right]$} \\
\hline$T_{\text {storage }}$ & duration of storage & [days] \\
\hline kdeg $_{\text {slurry }}$ & reaction constant transformation in slurry & {$\left[\right.$ day $\left.^{-1}\right]$} \\
\hline Qslurry & slurry immission standard & {$\left[\mathrm{kg} \mathrm{ha}^{-1}\right]$} \\
\hline$\rho_{\text {soil }}$ & bulk density of soil & {$\left[\mathrm{kg} \mathrm{m}^{-3}\right]$} \\
\hline DEPTHfield & mixing depth with soil & [m] \\
\hline $\mathrm{CONV}_{\text {area field }}$ & conversion factor for the area of the agricultural field & {$\left[\mathrm{m}^{2} \mathrm{ha}^{-1}\right]$} \\
\hline \multicolumn{3}{|c|}{ Intermediate results } \\
\hline$Q_{\text {excreted }}$ & amount substance excreted & {$\left[\mathrm{mg}_{\mathrm{c}}\right.$ place $^{-1}$ year $\left.^{-1}\right]$} \\
\hline$C_{\text {slurry }}$ & concentration in slurry & {$\left[\mathrm{mg}_{\mathrm{c}} \mathrm{kg}^{-1}\right]$} \\
\hline \multicolumn{3}{|l|}{ Output } \\
\hline PECsoil & predicted environmental concentration of the chemical in the soil & {$\left[\mathrm{mg}_{\mathrm{c}} \mathrm{kg}_{\mathrm{soil}}{ }^{-1}\right]$} \\
\hline
\end{tabular}

Empirical data on slurry concentrations and soil concentrations obtained in controlled studies (e.g. with spiked manure) are most useful for the empirical validation of this model, but are scarce in public literature. Data from studies performed in the UK, Germany, Italy and the USA are discussed below.

The data for the veterinary antibiotic sulfachloropyridazine (SCP) obtained in a field experiment in the United Kingdom are deemed useful to verify the soil concentration function (Boxall et al., 2002). This field experiment was performed with spiked manure spread over a sand soil and a clay soil, and all terms in the model described above were controlled. Soil properties were as follows: clay soil: Ap horizon $(0-37 \mathrm{~cm})$ sand $43 \%$, silt $32 \%$ clay $25 \%, \mathrm{pH}$ 6.8, \%o.c. 2.2; sand soil: Ap horizon $(0-37 \mathrm{~cm})$ sand $69 \%$, silt $21 \%$ clay $10 \%$, pH 6.6, \%o.c. 1.3

The sand soil was amended with slurry containing SCP at a concentration that would result in a nominal concentration in our standard models of $440 \mathrm{\mu g} \mathrm{kg}^{-1}$. Corrected for the actual soil bulk density of the soil, the nominal concentration amounts to $393 \mu \mathrm{g} \mathrm{kg}^{-1}$ dry weight (dw). The initial concentrations measured in the field study range from 232 to $669 \mathrm{\mu g} \mathrm{kg}^{-1} \mathrm{dw}$ (averaged over $20 \mathrm{~cm}$ depth) and were overall in close agreement (factor $<2$ ) to the predictions. The clay soil was amended with slurry containing SCP at a level that would result in a nominal concentration, corrected for the actual soil bulk density, of $500 \mathrm{\mu g} \mathrm{kg}^{-1} \mathrm{dw}$. The range of SCP concentrations (averaged over $20 \mathrm{~cm}$ depth) in the field was highly variable, ranging between the limit of detection and $120 \mathrm{\mu g} \mathrm{kg}^{-1}$.

In the clay, soil predictions and measurements were not in agreement. Assuming a normal distribution for the field measurements, regression analysis indicated that $90 \%$ of the distribution of soil concentrations is within a range of $8-145 \mathrm{\mu g} \mathrm{kg}^{-1} \mathrm{dw}$ soil. The modelled concentration of $500 \mathrm{~g} \mathrm{~kg}^{-1}$ corresponds to the 0.11 percentile of this distribution. The probability of sampling and finding a concentration at $500 \mathrm{\mu g} \mathrm{kg}^{-1}$ or greater is only $0.11 \%$, which makes it unlikely that the nominal concentration has been present anywhere in the field. Thus, the screening model did not predict the measured field concentrations in clay very well. Spatial heterogeneity may have accounted partly for these deviations (Vischetti et al., 1997), irreversible binding of the test substance to the soil could also be considered, or 
alternatively, about $90 \%$ of the SCP was lost between spiking of manure and analysis of clay soil samples.

Another paper contained empirical data from Germany on both soil and slurry concentrations of a veterinary medicine. Soil concentrations of $15 \mu \mathrm{g}$ sulfadimidine $\mathrm{kg}^{-1}$ soil were found in eastern Westphalia (Germany) in January 2002, in soil where 7 months earlier pig slurry had been applied (Christian et al., 2003). Pig slurry from the same location as used on the soil, although sampled some 4 months after this soil amendment, contained sulfadimidine at a concentration of $1.1 \mathrm{mg} \mathrm{kg}^{-1}$ wet weight. Assuming incorporation to $30 \mathrm{~cm}$ in a soil with a dry bulk density of $1740 \mathrm{~kg} \mathrm{~m}^{-3}$, the authors argued that the soil concentration was explained by the slurry concentration. However, since it concerns different batches of slurry, this argumentation is highly speculative unless antibiotic use and operational factors were constant throughout the study period.

The UK field study cited above was only concerned with the soil compartment, not with the slurry compartment. Using the data reported by Hamscher et al., 2000 and Hamscher et al., 2002 on tetracyclines (tetracycline (TC), chlortetracycline (CTC), oxytetracycline (OTC)), a comparison was made between model calculations for one animal type (sows) and one dosage, and measurements in both slurry and soil. Two screening models were used: the Spaepen model (Spaepen et al., 1997) and the RIVM model (Montforts, 1999); both models were designed to generate realistic worst-case concentrations in slurry and subsequently in soil, in support of the risk assessment at registration. In the model calculations, per place only one sow per year was supposed to be present, dosed with tetracyclines at $40 \mathrm{mg} \mathrm{kg}^{-1}$ bw for 5 days. The excretion factor was set to 1 . The degradation rate, expressed in the half-life DT50, for tetracyclines as a group may vary between 4 and 175 days, depending on for matrix, aeration or temperature (Soulides et al., 1962, Vej-Hansen et al., 1978, Gavalchin and Katz, 1994, Kühne et al., 2000, Ingerslev et al., 2001, Winckler and Grafe, 2001a and Lumaret and Errouissi, 2002). In the calculations, the degradation was conservatively assumed negligible. Feeding these figures into the Spaepen model, soil concentrations of 75 $\mu \mathrm{g} \mathrm{kg}^{-1}$ dry weight were expected (Fig. 1). The model calculations presented by Spaepen et al. (1997) were underestimating both the mean initial and the maximum concentrations for tetracyclines (TC, OTC and CTC). In the RIVM model, the upper limit for the predicted soil concentrations was $207 \mathrm{\mu g} \mathrm{kg}^{-1}$ dry weight. Measurements reported were below or just above the RIVM prediction. The authors noted however that the measured soil concentrations were a factor 2-4 higher than expected based on the corresponding measured slurry concentrations, and considered that this difference indicated the presence of residues in the soil, additional release of bound residues between the sampling in the years 2000 and 2001, or higher application volumes than stated (Hamscher et al., 2002). Feeding the figures used above into the RIVM model, it predicted a maximum concentration of $52 \mathrm{mg} \mathrm{I}^{-1}$ in slurry at a dosage of $40 \mathrm{mg} \mathrm{kg}^{-1}$ for 5 days (fattening pigs), which resulted in the predicted $207 \mathrm{\mu g} \mathrm{kg}^{-1}$ in soil. Winckler and Grafe (2001c) found in German pig breeding facilities mean tetracycline concentrations of $11.6 \mathrm{mg} \mathrm{I}^{-1}$ and a maximum concentration of $66 \mathrm{mg} \mathrm{I}^{-1}$ in slurry. Compared to these data, the measured concentration in the 'controlled' slurry samples of only $4 \mathrm{mg}^{-1}$ reported in (Hamscher et al., 2002) was indeed low. An explanation may be that, due to incomplete mixing of the slurry matrix before the slurry sample is taken, strongly sorbed substances may have concentrated in the solid fraction in deeper layers. Measured concentrations in the liquid fraction may hence have lead to underestimation of the total substance load present. 


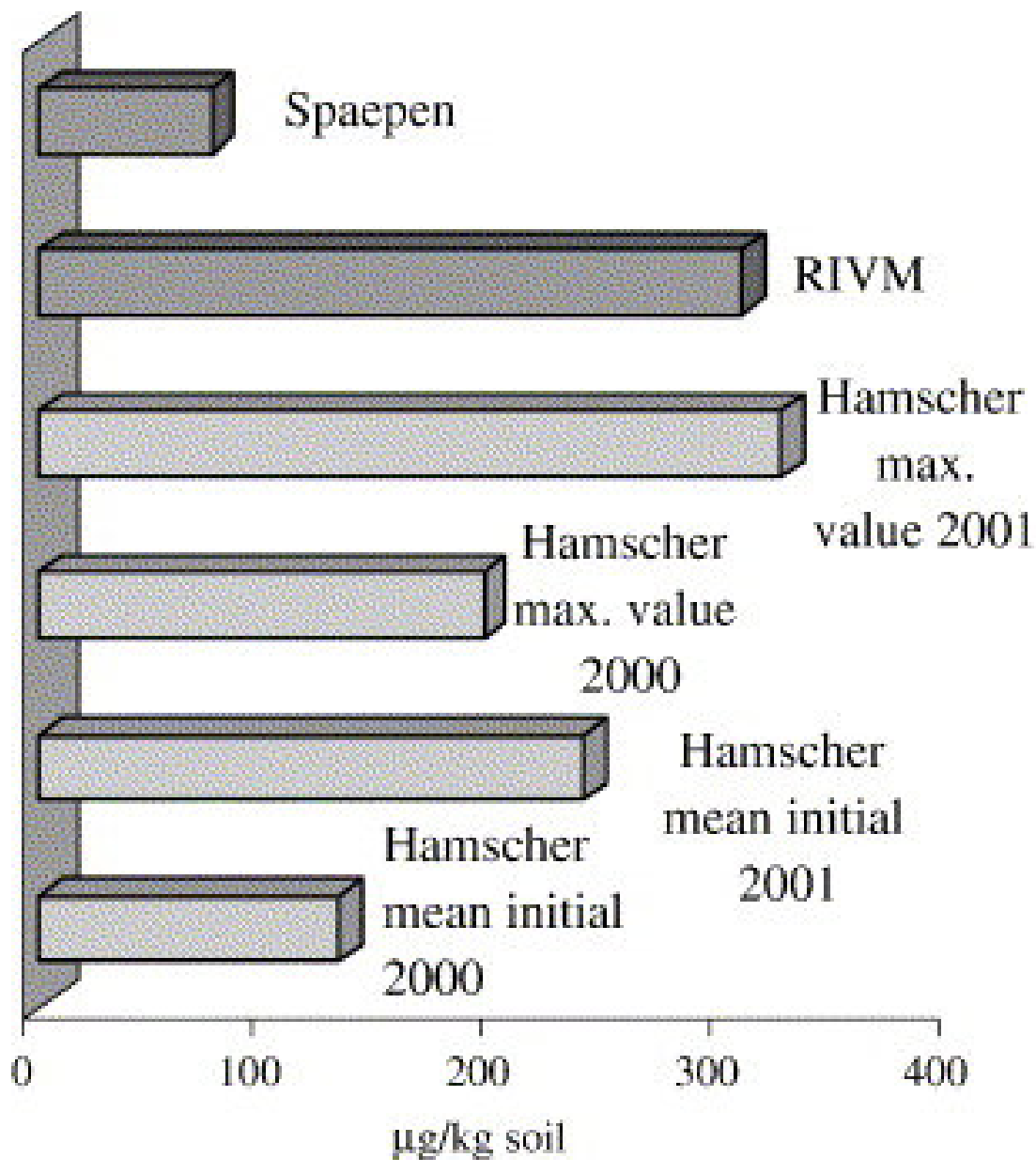

Fig. 1. Graphical presentation of initial PEC calculations for fattening pigs dosed at $40 \mathrm{mg}$ OTC/kg for 5 days compared to mean initial and maximum measurements of OTC in soil in Germany.

The soil sub-routine in the RIVM model tends to be conservative in predicted exposure levels, which satisfies the need to err on the safe side in the screening phase of a regulatory risk assessment. In particular, the prediction of the slurry concentration is challenged by uncertainties concerning dilution, mixing and dissipation of residues.

\subsection{Functional validation for surface water}

Three screening level models used for registration were available for surface water. The EMEA and RIVM models both contain a transport subroutine (soil-to-water transport rate) and a catchment subroutine (distribution and concentration in surface water) (EMEA, 1997 and Montforts, 1999). The models are conceived around one algorithm (an export coefficient depending on sorption properties and a static water volume). The RIVM model assumes a dilution factor of 10 and describes the transfer as follows:

$$
\begin{aligned}
& \text { PECsw }_{\text {leaching }}=\frac{\text { PECporewater }}{\text { DILUTION }_{\text {laching }}} \\
& \text { PECporewater }=\frac{\text { PECsoil } \rho_{\text {soil }}}{K_{\text {soil }- \text { water }} 1000}
\end{aligned}
$$




$$
\begin{gathered}
K_{\text {soil }- \text { water }}=\mathrm{Fwater}_{\text {soil }}+\mathrm{Fs}_{\text {solid }} \text { soill } \\
\mathrm{Kp}_{\text {soil }}=\mathrm{Foc}_{\text {soil }} \cdot \mathrm{Koc} .
\end{gathered}
$$

The EMEA model assumes a dilution factor of 3.3 and describes the partitioning function as follows.

$$
\text { PECporewater }=\frac{\text { PECsoil }}{\text { Foc }_{\text {soil }} \text { Koc }} \text {. }
$$

For both models, the explanation of symbols is in Table 2. In this methodology, the concentration in surface water depends on the concentration in soil as a result of spreading of slurry. The degree of surface water contamination in these lower level exposure models is not related to the actual transport processes (erosion, run-off and drainage), the ratio between treated soil and receiving surface water, nor to the distance to the surface water. The screening models consider that the soil to water transfer is linked exclusively to the soil porewater concentration, which is estimated from equilibrium processes based on the Koc or related parameters, followed by a dilution factor between soil porewater and surface water. It is also assumed that substances with Koc $>500 \mathrm{I} \mathrm{kg}^{-1}$ will not be transferred to water (EMEA, 1997).

\begin{tabular}{|c|c|c|}
\hline \multicolumn{3}{|l|}{ Input } \\
\hline DILUTION $_{\text {leaching }}$ & dilution factor for leaching & \\
\hline PECsoil & concentration in the soil & {$\left[\mathrm{mg}_{\mathrm{c}} \mathrm{kg}_{\mathrm{soil}}{ }^{-1}\right]$} \\
\hline$\rho_{\text {soil }}$ & fresh bulk density of soil & {$\left[\mathrm{kg} \mathrm{m}^{-3}\right]$} \\
\hline$\tilde{n}_{\text {solid }}$ & density of soil solids & {$\left[\mathrm{kg} \mathrm{m}^{-3}\right]$} \\
\hline Fair $_{\text {soil }}$ & fraction air in soil & {$\left[\mathrm{m}^{3} \mathrm{~m}^{-3}\right]$} \\
\hline Fwater $_{\text {soil }}$ & fraction water in soil & {$\left[\mathrm{m}^{3} \mathrm{~m}^{-3}\right]$} \\
\hline Fsolid $_{\text {soil }}$ & fraction solids in soil & {$\left[\mathrm{m}^{3} \mathrm{~m}^{-3}\right]$} \\
\hline Foc $_{\text {soil }}$ & fraction organic carbon in soil (w/dw) & {$\left[\mathrm{kg} \mathrm{kg}^{-1}\right]$} \\
\hline Koc & partition coefficient organic carbon-water & {$\left[\mathrm{dm}^{3} \mathrm{~kg}^{-1}\right]$} \\
\hline \multicolumn{3}{|c|}{ Intermediate results } \\
\hline$K_{\text {soil-water }}$ & partition coefficient solids and water in soil (v/v) & {$\left[\mathrm{m}^{3} \mathrm{~m}^{-3}\right]$} \\
\hline $\mathrm{Kp}_{\text {soil }}$ & partition coefficient solids and water in soil $(\mathrm{v} / \mathrm{w})$ & {$\left[\mathrm{dm}^{3} \mathrm{~kg}^{-1}\right]$} \\
\hline PECporewater & predicted concentration in porewater & {$\left[\mathrm{mg}_{\mathrm{c}} \mathrm{I}^{-1}\right]$} \\
\hline \multicolumn{3}{|l|}{ Output } \\
\hline PECsW leaching $_{\text {la }}$ & predicted concentration in surface water & {$\left[\mathrm{mg}_{\mathrm{c}} \mathrm{l}^{-1}\right]$} \\
\hline
\end{tabular}

Table 2.

Explanation of symbols for the surface water exposure functions

The VetPec model is more complex, consisting of a run-off model and an aquifer model that accompany the soil concentration model that follows the Spaepen model described above. Distribution of chemicals between porewater and solids are calculated using fugacity equations. The aquifer and catchment sub-models are capacity models consisting of cells with a limited number of variations in parameter properties, parameterised on English aquifers and river water catchments. Every time step, substance degradation, inflow and outflow are calculated, after which a new equilibrium is obtained (MacKay et al., 1986). The surface water predictions by VetPec have been validated with a selection of monitoring data on the pesticide isoproturon. The hydrology in the models was however not validated. No validation on less mobile compounds has been performed (WRc-NSF, 2001). 
These three models were subjected to an empirical validation using data from the field experiment with the veterinary antibiotic SCP performed in the United Kingdom (Boxall et al., 2002). In the sand soil, soil porewater concentrations of SCP had been measured and, in the clay soil, drain water concentrations had been measured. The fate in the receiving water compartments was however not assessed. The validation of the fugacity models in VetPec was hampered by this approach, since the transfer rates ought to be validated and not the equilibrium concentrations. This validation exercise generated highly variable and unsatisfying results, as shown in Table 3 . These model approaches did not perform satisfactorily as a screening tool.

Table 3.

A summary of model calculations for surface water and peak drain flows in the UK field experiment with SCP (Boxall et al., 2002)

\begin{tabular}{|c|c|c|c|c|c|c|c|c|}
\hline \multirow[t]{2}{*}{$\begin{array}{l}\text { Soil } \\
\text { type }\end{array}$} & \multirow[t]{2}{*}{$\begin{array}{l}\text { Nominal } \\
\text { soil conc. } \\
{\left[\mu \mathrm{kg}^{-1}\right]}\end{array}$} & \multirow[t]{2}{*}{$\begin{array}{l}\text { VetPec max. } \\
\text { value } \\
\text { porewater }\end{array}$} & \multirow[t]{2}{*}{$\begin{array}{l}\text { VetPec } \\
\text { surface } \\
\text { water }\end{array}$} & \multirow[t]{2}{*}{$\begin{array}{l}\text { EMEA } \\
\text { ground } \\
\text { water }\end{array}$} & \multirow[t]{2}{*}{$\begin{array}{l}\text { EMEA } \\
\text { surface } \\
\text { water }\end{array}$} & \multirow[t]{2}{*}{$\begin{array}{l}\text { RIVM } \\
\text { surface } \\
\text { water }\end{array}$} & \multicolumn{2}{|c|}{$\begin{array}{l}\text { Peak flow from } \\
\text { drainpipe (clay) or } \\
\text { soil porewater (sand) } \\
\left(\text { LOD } 0.25 \mu \mathrm{g} \mathrm{I}^{-1} \text { ) }\right.\end{array}$} \\
\hline & & & & & & & Year 1 & Year 2 \\
\hline Sand & 393 & 0.84 & 0.01 & 370 & 112 & 37 & 0 & 0 \\
\hline Clay & 500 & $\mathrm{nc}$ & 0.01 & $\mathrm{nc}$ & 74 & 26 & 589 & 6 \\
\hline
\end{tabular}

All results are in $\mu \mathrm{g} \mathrm{I}^{-1} . \mathrm{nc}=$ not calculated.

Few data on surface water contamination by medicines and hormones via land are found in literature. A selection is briefly discussed below to add further considerations to the validity of screening level surface water exposure models. Ivermectin has a sorption coefficient $K_{\mathrm{om}}$ of $4500-5500 \mathrm{~kg}^{-1}$ and is rather persistent in soil with degradation half-lives DT50 (determined at $22{ }^{\circ} \mathrm{C}$ under laboratory conditions) of 93 to 240 days (mean 187 days, $n=4$ ) (Halley et al., 1989). Transport of ivermectin by drainage is to be considered negligible, since this route is not assessed in the EMEA model at Koc $>500 \mathrm{I} \mathrm{kg}^{-1}$. In a study on run-off from cattle feedlots in the United States, only trace amounts (up to $2 \mathrm{ng} \mathrm{l}^{-1}$ ) of ivermectin were indeed detected occasionally (Nessel et al., 1989). Oxytetracycline shows strong adsorption behaviour in soils with log Koc of 4-5 (Rabølle and Spliid, 2000). In an Italian study, no oxytetracycline was detected in drainage ditches adjacent to treated fields (LOD $1 \mu \mathrm{g} \mathrm{I}^{-1}$ ) (De Liguoro et al., 2003), which is consistent with the EMEA model trigger for surface water exposure. In an US investigation, $31 \%$ of the water samples proximal to swine farms and $67 \%$ of the samples proximal to poultry farms were found to contain antimicrobial compounds used in these farms: chlor-, oxy- and tetracycline, sarafloxacin, lincomycin and sulfadimethoxine, generally at levels $<4 \mu \mathrm{g} \mathrm{I}^{-1}$ (Campagnolo et al., 2002). In the UK field study, mass losses from soil into drainage water accounted for not more than $0.5 \%$ of the dose applied to the soil. Peak concentrations of oxytetracycline were $36 \mu \mathrm{g} \mathrm{I}^{-1}$. For sulfachloropyridazine, the peak concentration was $613 \mu \mathrm{g} \mathrm{I}^{-1}$ (Kay et al., 2004). Of sarafloxacin and related fluoroquinolones, the log Koc is reported to be 5-6 (Nowara et al., 1997 and AHI, 1999). However, the concentrations of tetracyclines and sarafloxacin reported in water $\left(1-36 \mu \mathrm{g} \mathrm{I}^{-1}\right.$ and $4 \mu \mathrm{g} \mathrm{I}^{-1}$, respectively) do not support the above-mentioned EMEA model trigger. These scarce data cast further doubt on the applicability of the surface water exposure models for screening purposes.

Veterinary pharmaceuticals are released into the soil as part of an organic matter rich matrix, and it is well known that organic amendments including manure can increase but also decrease the adsorption of chemicals to soil (Iglesias-Jimenez et al., 1997 and Morillo et al., 2002). In addition, the direct transfers of the non-dissolved chemical fraction should be considered. The transfer of particle-bound fractions is particularly important for run-off, while colloidal associations should be considered for drainage since the fraction bound to small particles could also be relevant for preferential flow via macropores. For example, the sorption of oestradiol-17 $\beta$ is associated with the surface area and/or the cation exchange capacity of the soil, with high correlation to particle size (clay) and organic matter. $K_{\mathrm{F}}$ values for this 
substance were in the range of $86-6670 \mathrm{I} \mathrm{kg}^{-1}$, with $K_{\text {om }}$ values of $1800-72500 \mathrm{I} \mathrm{kg}^{-1}$ (median $2600 \mathrm{~kg}^{-1}$ ) (Casey et al., 2003). In soil column leaching studies performed with oestradiol$17 \beta, K_{\mathrm{om}}$ values ranging from 950 to $1700 \mathrm{I} \mathrm{kg}^{-1}$ were determined. The strong sorption did not appear to hinder degradation; degradation half-life values of $0.4-10$ days were determined (Das et al., 2004). Nevertheless, from experimental plots treated with horse stall bedding or poultry litter, $20 \%$ and $30 \%$, respectively, of the added amount of oestradiol- $17 \beta$ was transported in run-off directly following a simulated storm. In the poultry litter experiment, the total loss in a second simulated storm event seven days later was $69 \%$ of the first loss, which is in proportion with the load remaining after the first event (Nichols et al., 1997 and Busheé et al., 1998).

The screening level models tend to be conservative in predicting exposure levels, which satisfies the need to err on the safe side in the screening phase. However, the trigger value for surface water exposure clearly obscures the possibility of transport of strongly sorbing substances.

\subsection{Functional validation for groundwater}

With respect to groundwater, in Phase I of the EMEA Note for Guidance, the concentration in the ground water is set equal to the concentration in the porewater (EMEA, 1997). The EMEA scheme suggests that the PECsoil as calculated for the upper layer is the input term for the calculation. Conceptually, in this model, the groundwater table reaches to the mixing depth defined by the soil concentration module, or it supposes complete vertical transposition of the residue to the depth of the groundwater table. In this model, partitioning depends on equilibrium sorption to solids, no saturation at binding places and steady-state conditions. Movement, dilution, desorption and transformation are not modelled. As explained in the previous section, in VetPec, the distribution of chemicals between porewater and solids are calculated using fugacity functions.

In Table 3, a comparison is made between the predictions and the porewater measurements of SCP in the UK field experiment (Boxall et al., 2002). The accuracy of the partitioning model predictions depended strongly on the soil layer to which the measurements were standardised. If a $5 \mathrm{~cm}$ layer was chosen instead of the current $20 \mathrm{~cm}$, calculated concentrations would have been four times higher. In any case, all calculations have overestimated the actual porewater concentrations. The maximum drainflow concentration from the clay field in the first year (Table 3) corresponded reasonably with the EMEA porewater calculation. The field measurements are clearly the result of preferential flow of both solutes and manure-associated particles through soil cracks following a massive rain event. The second year the soil had been tiled and disked, thus cutting off the cracks that lead to the drainpipes, resulting in lower concentrations. Again, these model approaches did not perform satisfactorily as a screening tool.

\section{Scenario development for EU registration}

The emission route from slurry to soil and water is unmistakably an important route and a complex one. A critical component for the registration procedure is the identification of relevant scenarios. Since at the screening stage of the exposure assessment already decisions are made on the acceptability of the environmental risk, regulatory authorities have to be careful in choosing exposure scenarios (Montforts et al., 1999). The actual use pattern of the product should be explored, because repetitive use, season-related use or concurrent uses over large areas, in relation to the timing and scale of emission to the environment (i.e. spreading of manure), have a significant impact on the actual exposure.

\subsection{Scenario parameters}

The exposure modelling investigated above can be split in three major subroutines: one for the animal husbandry phase, one for the slurry handling and one for the environmental phase. The situation of interest that is to be modelled defines the respective parameter values. A 
specific combination of parameter values is denoted a scenario. The following variables and scenario parameters need to be observed in the scenario and have to be addressed, either as a parameter or by default: emission, storage, substance behaviour during storage, immission into soil, substance behaviour in soil and water, and environmental conditions.

\subsubsection{Emission}

Disease incidence and dosage are static parameters, since in the risk assessment at registration the modelling is performed using a given prescribed dose to a target animal. Several target animals have more production cycles in one year, which may all need treatment. Depending on the relation between animal cycles and manure storage in the model, a certain number of cycles should be observed in the emission module. Excretion of residues is also an input-parameter in the model. Excretion patterns and cumulative excretion may differ depending on species, race, mode of application and dosage. Data reported in literature suggest that total cumulative excretion may range from 0.2 to 1 and the excretion time from 1 and 100 days, depending on species, substance, dosage and route of administration (Short et al., 1987, Halley et al., 1989, Lumaret et al., 1993, Herd, 1995, Strong et al., 1996, Ramazza et al., 1996 and Winckler and Grafe, 2001c). Although the parent compound may be transformed into transformation products, the conjugates may be reverted in the slurry to active compounds (Henschel et al., 1997 and Panter et al., 1999) and others may have some activity themselves (Schowanek and Webb, 2002). Excretion of metabolites may hence contribute to the effects of the parent compound.

\subsubsection{Storage}

The input, storage and outflow of contaminated and uncontaminated slurry determine the loads that will reach the soil. Different animal types may contribute to the same slurry storage system and the treated animals do not exclusively determine final concentrations. Slurry production and quality is monitored more or less intensively in EU countries due to the restrictions in the use of fertilisers. The figures in the publications are not always comparable, as they may refer to some (adult) individuals or to the total husbandry system (including young) and are not always identical (due to differences in feed, race and housing conditions). Body weights at treatment are proposed based on adult weights for parent animals and the mean of slaughter weight and starting weight for production animals. Depending on the physical state of the manure, the manure is kept in bedding, piled or stored in tanks or lagoons. Proportions of manure types and storage systems differ considerably between countries (Menzi, 2002). Depending on structure and handling, the manure can be aerobic or anaerobic and there will be a great variation in temperature, redox potential, $\mathrm{pH}$, and storage time of the slurry. Different manure types and storage systems will influence storage conditions and manure composition in different ways (Donham et al., 1988). Conditions like oxygen levels, manure age, microbial activity and temperature will determine the fate of organic contaminants to a large extent, but are highly diverse within and between storage systems (Hoeksma et al., 1987, Novem, 1991, Jenkins et al., 1997, Pitts et al., 1998, Richard et al., 1998, Arogo et al., 1999, Qiang, 1999, Moreira, 2001 and Schiffer et al., 2001). Depending on climate, season, storage systems and manure structure, temperatures can range from ambient (freezing) to $65^{\circ} \mathrm{C}$ (composting) (Kelley et al., 1994 and Eghball, 1998). For underground slurry storage systems, this range can be narrowed down, because average soil temperatures for Europe range from 4 to $18{ }^{\circ} \mathrm{C}$ (FOCUS, 2000). For storage of solid manure (piles, containers), temperatures can be quite higher and varying due to composting processes (until anaerobicity is reached). The most realistic period in which storage can take place cannot be determined with a rule of thumb. Storage time is a function of manure output and substance and manure input. Since these functions largely depend on the (unknown and individual) substance prescriptions, disease patterns and manure management, either a complete manure model with detailed inputs is needed or a scenario for every livestock category of interest has to be defined. In the latter option, dosing, excretion and manure handling are made part of the scenario rather than of the model algorithms. Given the sheer endless variability described above, the slurry storage, production and removal should be defined in scenarios for screening level models. 


\subsubsection{Soil immission patterns}

Agricultural practices will play a very important role in determining the concentrations of veterinary drugs in the environment. Livestock manure is the second most important source of nutrient inputs to agricultural land (Pau Vall and Vidal, 2001). The pattern of agriculture and manure use can vary widely from one region to another. The nutrient content of manure varies from country to country and from one region to another within a country (Provolo and Riva, 2002). To provide harmonised realistic worst case estimates, the lower nitrogen production standards presented to the European Resource Management of the European Commission DG XI (Ketelaars and Van der Meer, 2000) are proposed (Table 4). Storage systems differ between countries and animal types. The frequency at which slurry is taken out of the storage facilities can have a different timing. For example, for cattle and pig slurry, seven respectively three moments are considered by (Tijmensen et al., 2002). Another source reports average slurry storage times of 9 months (range $0-50$ months), but it is not specified to what animals the data apply (WRc-NSF, 2000). Spreading events are monitored at regional levels (Berende, 1998, ADAS, 1998 and Van Staalduinen et al., 2001). In the Netherlands and in Belgium, over $95 \%$ of the agricultural (arable) land is manured one to three times per year. The manure produced by livestock will be applied to land, the amount applied being dependent on immission limits for nitrogen and phosphorus, fertiliser recommendations, soil type or crop tolerance for slurry. These limits, which are designed to avoid the excessive input of nutrients in soils, vary across member states. For example in Italy, at national level, the maximum amount of manure, which can be applied to land that is not designated as a vulnerable area, is the annual production from $4 \mathrm{t}$ live weight ha ${ }^{-1}$ without regard of animal species (Bonazzi, 2002). Based on the data in Table 4, the annual load may range up from $275 \mathrm{~kg} \mathrm{~N} \mathrm{ha}^{-1}$ for turkeys to $550 \mathrm{~kg} \mathrm{~N} \mathrm{ha}^{-1}$ for dairy cows. The exact amount that is allowed will depend on the way the production per hectare is quantified over the year, and the nitrogen content of the manure produced. The amount of slurry that is actually applied (in one time) will depend on many other practical factors. A different situation is found in the Netherlands, that designated its entire territory as a vulnerable area under the EU Nitrate Directive $(91 / 676 / E C)$. This directive applies to areas that are vulnerable to leaching of nitrate in all member states and the nitrogen immission standard of $170 \mathrm{~kg} \mathrm{~N} \mathrm{ha}^{-1}$ can be considered as a realistic best case for these areas. Incorporation depths have been recorded in an inventory by WRc-NSF (WRc-NSF, 2000). Plough depths for slurry and solid manure were in the range of $0-28 \mathrm{~cm}$, with averages of $16.5 \mathrm{~cm}$. 
Table 4.

Standardised nitrogen production standards $\left(P_{\mathrm{N}}\right)$, rounds $\left(N_{\text {animal }}\right)$ and treatment body weights $\left(m_{\text {animal }}\right)$ for different livestock categories (Ketelaars and Van der Meer, 2000)

\begin{tabular}{|c|c|c|c|}
\hline Livestock & $\begin{array}{l}P_{\mathrm{N}}[\mathrm{kg} \mathrm{N} \\
\text { place }^{-1} \\
\left.\text { year }^{-1}\right]\end{array}$ & $N_{\text {animal }}$ & $m_{\text {animal }}$ [number of young per year] \\
\hline \multicolumn{4}{|l|}{ Cattle } \\
\hline Dairy cows & 60 & & $425 \mathrm{~kg}$ per adult, $25 \mathrm{~kg}$ per calf $\left(0.6\right.$ calves place $^{-1}$ year $\left.^{-1}\right)$ \\
\hline Other cows & 44 & & $425 \mathrm{~kg}$ per adult, $25 \mathrm{~kg}$ per calf $\left(0.6\right.$ calves place $^{-1}$ year $\left.^{-1}\right)$ \\
\hline Veal $^{\mathrm{a}}$ & 10 & 1.8 & $140 \mathrm{~kg}$ \\
\hline $0-1$ year & 18 & & $200 \mathrm{~kg}$ \\
\hline $1-2$ years & 31 & & $400 \mathrm{~kg}$ \\
\hline$>2$ years & 35 & & $450 \mathrm{~kg}$ \\
\hline \multicolumn{4}{|l|}{ Pigs } \\
\hline Sows with piglets till $25 \mathrm{~kg}$ & 32 & & $240 \mathrm{~kg}$ per adult, $9 \mathrm{~kg}$ per piglet ( 20 piglets place ${ }^{-1}$ ) \\
\hline Slaughter pigs $25-105 \mathrm{~kg}$ & 7.5 & 3 & $65 \mathrm{~kg}$ \\
\hline \multicolumn{4}{|l|}{ Poultry } \\
\hline Laying hens & 0.35 & & $1.6 \mathrm{~kg}$ \\
\hline Broilers, $1.8 \mathrm{~kg}$ & 0.23 & 9 & $1 \mathrm{~kg}$ \\
\hline Ducks, 3.3 kg & 0.41 & 7 & $1.6 \mathrm{~kg}$ \\
\hline Turkeys, $13 \mathrm{~kg}$ & 0.90 & 2.7 & $6.5 \mathrm{~kg}$ \\
\hline \multicolumn{4}{|l|}{ Sheep } \\
\hline Ewes with lambs till $40 \mathrm{~kg}$ & 13 & & $75 \mathrm{~kg}$ per adult, $20 \mathrm{~kg}$ per lamb (1.6 lambs place $\left.{ }^{-1}\right)$ \\
\hline \multicolumn{4}{|l|}{ Goat } \\
\hline Females with kids till $7 \mathrm{~kg}$ & 13 & & 65 adult, $3.5 \mathrm{~kg}$ per kid (1.8 kids place $\left.{ }^{-1}\right)$ \\
\hline \multicolumn{4}{|l|}{ Rabbit } \\
\hline Females with kittens & 3.9 & 6.75 births & $2 \mathrm{~kg}$ per adult, $1 \mathrm{~kg}$ per kitten (50 kittens place ${ }^{-1}$ ) \\
\hline \multicolumn{4}{|r|}{ 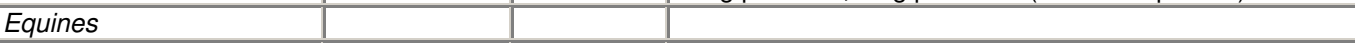 } \\
\hline Horses & 35 & & $400 \mathrm{~kg}$ \\
\hline
\end{tabular}

a Veal data based on Van Staalduinen et al. (2001) and Montforts (1999).

\subsubsection{Environmental conditions}

Climate and soils are important factors in the determination of chemical concentrations in the environment. In 1993, the European Commission and the European Crop Protection Association jointly established FOCUS (Forum for the Co-ordination of pesticide fate models and their USe), which, as one of its tasks, established standard leaching and surface water exposure scenarios for pesticide registration in Europe. The simple fact that this methodology encompasses the same agricultural fields that are relevant for manure application, predestined these scenarios to be applicable to residues spread by manure as well.

\subsection{Scenario development for spreading of manure}

A general lack of information on distributions of parameter values within and between systems forces one to propose the use of a deterministic model with empirical parameters, defined in a simple scenario of realistic and standardised conditions. The amount of slurry present in storage depends on the time of year and, depending on the number of cycles treated during this time, the concentration in the slurry is determined. A major difference between the two screening models that have been discussed is the time span in which clean manure is produced. The shorter this period, the higher the predicted manure concentrations will be. The amount of manure that is spread containing the residue of the treatment is delimited by the storage capacity of the system and the opportunities to take the slurry out. Most UK farms only have the capacity to store slurry for less than 1 month and in several 
other European countries from 1 to 12 months (Menzi, 2002). The depth of incorporation depends on the method of application. In the field, no incorporation has been registered as general agricultural practice. If manure is incorporated, the mean incorporation depth is 16.5 $\mathrm{cm}$. Maximum slurry loads ranged up to $550 \mathrm{~kg} \mathrm{~N} \mathrm{ha}^{-1}$ year $^{-1}$ and more. Realistic worst case conditions are hence proposed in a simple scenario assuming: single treatment per animal place, standard European nitrogen production values, a manure production volume of 1 month (30 days) containing the full residue, a nitrogen application rate of $600 \mathrm{~kg} \mathrm{~N} \mathrm{ha}^{-1} \mathrm{year}^{-1}$ in one time onto agricultural land, which is distributed over $5 \mathrm{~cm}$ soil with a bulk density of $1500 \mathrm{~kg} \mathrm{~m}^{-3}$, no dissipation during storage and no after-treatment of slurry. If the exposure calculation according to this scenario fails the trigger for further testing, safe use in all member states is possible. If not, then realistic best case conditions, characterising a possible safe use in vulnerable areas under the Nitrate Directive in the European Union, are proposed in a similar scenario, now assuming active incorporation of slurry into $20 \mathrm{~cm}$ of soil, at a nitrogen application rate of $170 \mathrm{~kg} \mathrm{~N} \mathrm{ha}^{-1} \mathrm{year}^{-1}$ in one time. If the trigger for further testing is exceeded, then further assessments should be made at the member state level, since environmental concerns can be a reason to refuse (mutual recognition of) marketing authorisation (Montforts et al., 2004).

The PECsoil can be used in conjunction with screening level models that predict mass transfer to groundwater and surface water. Both screening level and mechanistic models for distribution of residues from soil provided for pesticide registration by FOCUS are considered as suitable for veterinary drugs as for pesticides (FOCUS, 1995, Groen, 1997, FOCUS, 2000 and FOCUS, 2001). The simple fact that this methodology encompasses the same agricultural fields that are relevant for manure application predestined these models and scenarios to be applicable to residues spread by manure as well. Application timers in the models should be set to relevant regional conditions for manure application. These may depend on spreading restrictions and where these do not apply, by worst case conditions (e.g. autumn vs. spring conditions).

\section{Fish cultivation}

The scale of fish cultivation, dominated by land-based fish nurseries, for commercial purposes, is limited in the Netherlands. The production amounts to about $0.2 \%$ of the production of animal husbandry (Luiten, 2002). In 1994, in total, 26 and 10 companies were involved in cultivating eel and catfish, respectively. Most nurseries use water recirculation systems, in which the water is recycled after a water treatment by filtration. Catfish nurseries discharge on the municipal Sewage Treatment Plants (STP), but $40 \%$ of the eel nurseries discharge directly on surface water. Tropical fish nurseries may also contribute to the emission to surface waters (Schrap et al., 2003).

The surface water exposure scenarios discussed in Montforts et al. (1999) were based on a fish farm that breeds $50 \mathrm{t}$ of eel a year, the median production in The Netherlands. Two scenarios were distinguished, based on the incidence of administration of the product and the type of wastewater treatment: continuous medication; without recirculation/filtration, followed by a settlement tank; or occasional medication ( $\leq 4$ times a year), without recirculation/filtration before discharge to the settlement tank. After the settlement tank, the water fraction is discharged to surface water. The settling tank is used in order to reduce the amount of precipitation in the waste water before discharge into surface water or waste water treatment systems, but it was also assumed to play a significant role in reducing concentrations of chemicals in the waste water. It was assumed that the settling tank had a removal efficiency of $50 \%$. This removal efficiency was taken from Wagemaker (1993) and is an estimated value based on the average difference between pesticide concentrations that were measured in the influent and effluent of settling tanks used at mushroom production plants, as reported in Van Beersum (1988). Due to the settlement tank, the total amount of substance emitted was equally spread out over 25 days. In the exposure model, the fish farm discharges on a small waterway that dilutes the effluent by a factor 5 or 3 , depending on the water volume discharged. The surface water concentration was therefore constant for at least this 25 day emission period. 
In addition to the Van Beersum (1988) data set, data on the concentration of pesticides in wash water from flower bulb processing facilities were now analysed (Frijters, 2000). The two sets of data analysed contained a total number of 251 observations: individual concentrations of 41 pesticides in the influent and effluent of settling tanks at three different mushroom processing companies at five different time points (Van Beersum, 1988); and individual concentrations of 17 pesticides in the influent and effluent of settling tanks used in the washing of flower bulbs (Frijters, 2000). The difference between influent and effluent concentration, expressed as a percentage of the influent concentration, varied from $-571 \%$ (hence increase of concentration) to $100 \%$ removal. The 251 samples pairs show an averaged 'removal efficiency' of $-2.4 \%$. The median of the samples was at $17 \%$. Thus, if an indication of the removal efficiency can be derived from these data, the settlement tanks removed on average a negligible amount of the total load of pesticides. Perhaps more important is the (lack of) applicability of the model for the situation of interest. A reduction of the excess organic substances in effluent and an increase of water re-use are the major purposes of wastewater treatment in indoor fish production systems. In fish nursery water treatment systems, a very high concentration of organic matter in wastewater, but hardly any soil, can be expected (Kamstra and Van der Heul, 1998). A sub-routine describing the effect of sludge retention should thus used and not of soil settlement.

The emission pattern of treated water is of importance. Some treatments require stopping the water flow for some time, followed by transfer of fish to clean water. Therefore, a $100 \%$ immediate release should be expected for a worst case estimate. In the original model, emission of the residue was modelled over 25 days, but this retention factor lacks empirical or mechanistic underpinning. In the exposure model, the fish farm discharges on a small waterway that dilutes the effluent by a factor 5 or 3 , depending on the water volume discharged. In the Netherlands, about 60 domestic wastewater treatment plants (ca. 20\%) have a dilution factor of 2 within $100 \mathrm{~m}$ (De Greef and De Nijs, 1990). Whether or not the effluent flows of the fish nurseries are similar to those of the domestic treatment plants is unknown. Monitoring of effluent from a tropical fish nursery in the Netherlands, with presumably batch-like treatment, revealed concentrations of $11-41 \mathrm{\mu g} \mathrm{I}^{-1}$ for six therapeutics. The highest concentration found was $120 \mu \mathrm{g} \mathrm{I}^{-1}$ for oxytetracycline. Downstream of the effluent oxytetracycline was measured at a concentration of $57 \mu \mathrm{g} \mathrm{I}^{-1}$ (Schrap et al., 2003). A dilution factor of only two may be very well applicable to direct emission in low-flow ditches. Given the high sorption coefficient of oxytetracycline of log Koc 4-5 I kg ${ }^{-1}$ (Rabølle and Spliid, 2000), dissipation towards the sediment would be expected, but this was not investigated by Schrap et al. (2003). In another research, at the emission point of a tank-based aquaculture system for trout in northern Italy, a sediment concentration of $246 \mathrm{\mu g} \mathrm{kg}^{-1}$ dry weight was found (Lalumera et al., 2004).

This validation indicates that the surface water exposure model was not well founded, based on generalised data derived from situations that were not applicable. With the aim to eliminate no-risk situations from further assessment, a worst-case assumption would be that the therapeutic concentration would be the environmental exposure concentration. Further risk assessment will require the development of an applicable exposure model.

\section{Conclusions}

It is concluded that the original $50 \%$ removal efficiency of the settlement tank as used in Wagemaker (1993) and Montforts (1999) lacks empirical foundation since only part of the entire data set (the 'positive' efficiencies) had been used. There is no evidence that a settling tank contributes to removal of a substantial fraction of the total load of dissolved and particleassociated pesticides from wastewater. Monitoring data from a location with direct emission of fish nursery wastewater indicated a dissipation (or dilution) factor of 2 between effluent and downstream surface water concentrations. What dilution factor is most applicable to fish nurseries cannot be determined. Sediment contamination should be incorporated into the exposure model for registration purposes.

The empirical validation of the soil concentration models with (oxy)tetracycline and sulphonamides conducted indicate that it is far-fetched to analyse the contribution of every 
single model parameter to the variability in the model predictions using random field samples only. Not only variation in doses (a function of dosage and body weight) and excretion factors, dilution, degradation, slurry application rates and soil variability, but also factors such as representative sampling in slurry and soil, and field residue history, complicate the validation of this part of the model. A recent study from the USA confirms this conclusion (Zilles et al., 2005). It can be concluded that slurry or nutrient concentrations should be related to a realistic time frame in which the contaminated slurry is produced and diluted in order to optimise the worst case predictions; the available field data do not allow for validation of the parameter selection in the models; and that field concentrations may vary a factor 30 within one field. Surface water and groundwater models generated highly deviating predictions compared to the field results. What all models have in common is that soil porewater concentrations are exaggerated compared to the results of the sand soil in the field study, but not compared to the results of the clay soil. This provides reason to assume that surface water contamination is not controlled by sorption alone, and cut-off values on sorption properties are not warranted. A scenario for a simplified soil exposure model has been made, which can be used in conjunction with screening level models that predict mass transfer to groundwater and surface water. Both screening level and mechanistic models for distribution of residues from soil provided for pesticide registration by FOCUS are considered as suitable for veterinary drugs as for pesticides.

Interestingly, the predicted initial soil concentration using the proposed scenario in conjunction with Dutch default conditions, for a high volume compound like (oxy)tetracycline used in pigs or broilers, amounts to $200 \mathrm{\mu g} \mathrm{kg}^{-1}$ soil, with a possible maximum of $1000 \mu \mathrm{g}$ $\mathrm{kg}^{-1}$ soil (Montforts, 2003). The average concentration of antibiotics in soil based on the total annual consumption of $402 \mathrm{t}$ and the total capacity of agricultural fields to utilise manure in the Netherlands amounts to approximately $100 \mathrm{~g} \mathrm{~kg}^{-1}$ soil (Van Staalduinen et al., 2001 and MARAN, 2002). The difference between these results is within an order of magnitude, which suggests that regional scale modelling of soil concentrations may provide suitable approaches for protective risk assessments. The development of regional and catchment area models for assessing pesticides and other agrochemicals, but also manure-borne pathogens, is receiving significant attention (Walker and Stedinger, 1999, Deelstra et al., 2002, Arhonditsis et al., 2002 and Bicudo and Goyal, 2003). In particular, run-off and erosion in vulnerable areas of the Mediterranean region would be suitable processes for regional modelling. Recent studies demonstrate the influence of particle-bound fractions in regional transport modelling and the relevance of erosion in the overall transfer of organic matter from soil to watersheds. These findings suggest that the contribution of these mechanisms can be higher than expected, particularly for chemicals with a high binding potential (McLachlan et al., 2002 and Polyakov and Lal, 2004). Smith et al. (2001) observed relevant contributions of surface run-off including particles losses for manure applications over 2.5-3.0 tha $^{-1}$ slurry solids in UK arable lands. But due to the higher run-off/erosion risk of the Mediterranean region a lower threshold should be considered for this area (Arhonditsis et al., 2002). Tentatively, screening assumptions could be made on the basis of simplistic models, correlating directly the concentration in the topsoil layer with the expected concentration in the run-off. These models have initially been developed for herbicides. They describe non-linear relationships, with an extraction coefficient representing removal of the pesticide from the top $1 \mathrm{~cm}$ soil layer and an exponent representing reductions in the extraction potential with ageing (Leonard et al., 1979 and Southwick et al., 2003). Additional alternatives are the use of total losses, which may be implemented through probabilistic models (Pablos et al., 1998). The suitability of these models for pharmaceuticals should be studied. It should be, however, recognised that addressing these transfer routes requires regional models, which cannot be implemented as generalised screening tools.

\section{Acknowledgements}

This publication was funded by the EU Energy, Environment and Sustainable Development Programme of the Fifth Framework Programme, within the project Environmental Risk Assessment of Veterinary Medicines in Slurry, ERAVMIS, contract number EVK1-CT-199900003, and of the Netherlands Ministry of VROM, within the RIVM project M/601450 Development of Risk Assessment Methodology. The author is solely responsible for the 
Science of The Total Environment Volume 358, Issues 1-3 , 1 April 2006, Pages 121-136

contents, which does not represent the opinion of the Community. The contributions of José Tarazona and Rikkert Hansler and of two anonymous reviewers are gratefully acknowledged.

\section{References}

ADAS, 1998 ADAS. Animal manure practices in the beef industry. ADAS Market Research Team report for MAFF, 1998.

Addiscot and Wagenet, 1985 T.M. Addiscot and R.J. Wagenet, Concepts of solute leaching in soils: a review of modelling approaches, J Soil Sci 36 (1985), pp. 411-424.

Addiscot et al., 1995 T. Addiscot, J. Smith and N. Bradbury, Critical evaluation of models and their parameters, $J$ Environ Qual 24 (1995), pp. 803-807.

Aga et al., 2003 D.S. Aga, R. Goldfish and P. Kulshrestha, Application of ELISA in determining the fate of tetracyclines in land-applied livestock wastes, Analyst 128 (2003), pp. 658-662.

$\mathrm{AHI}, 1999 \mathrm{AHI}$, Analysis data and information to support a $\mathrm{PEC}_{\text {soil }}$ trigger value for phase I (A retrospective review of ecotoxicity data from environmental assessments submitted to FDA/CVM to support the approval of veterinary drug products in the United States from 1973-1997), Animal Health Institute, Environmental Risk Assessment Working Group, USA (1997).

Anonymous, 1991 Anonymous. Council Directive 91/676/EEC of 12 December 1991 concerning the protection of waters against pollution caused by nitrates from agricultural sources. 1991.

Anonymous, 2001 Anonymous. Directive 2001/82/EC of the European Parliament and of the Council of 6 November 2001 on the Community code relating to veterinary medicinal products. 2001.

Anonymous, 2004 Anonymous. Directive 2004/28/EC of the European Parliament and of the Council of 31 March 2004 amending Directive 2001/82/EC on the Community code relating to veterinary medicinal products. 2004.

Arhonditsis et al., 2002 G. Arhonditsis, C. Giourga, A. Loumou and M. Koulouri, Quantitative assessment of agricultural runoff and soil erosion using mathematical modeling: applications in the Mediterranean region, Environ Manage 30 (2002), pp. 434-453.

Arogo et al., 1999 J. Arogo, R.H. Zhang, G.L. Riskowski and D.L. Day, Mass transfer coefficient for hydrogen sulfide emission from aqueous solutions and liquid swine manure, Trans ASAE 42 (1999), pp. 1455-1462.

Berende, 1998 P.L.M. Berende, Praktische kengetallen over fokkerij, huisvesting, voeding, lichaamssamenstelling, urine-en fecesproductie en toediening van diergeneesmiddelen bij het rund, Rikilt-DLO, Wageningen, The Netherlands (1998) 98.10.

Bicudo and Goyal, 2003 J.R. Bicudo and S.M. Goyal, Pathogens and manure management systems: a review, Environ Technol 24 (2003), pp. 115-130.

Bonazzi, 2002 Bonazzi G. Case study in intensive pig production in Italy. http://lead.virtualcentre.org/en/ele/awi_2000/particip/csitaly.htm, 2002. Date of access 2004.

Boxall et al., 1997 A.B.A. Boxall, C.D. Watts and P. Ripley, The application of predictive models for the environmental risk assessment of ECONOR@, J Vet Pharmacol Ther 20 (1997), p. 331.

Boxall et al., 2002 A.B.A. Boxall, P. Blackwell, R. Cavallo, P. Kay and J. Tolls, The sorption and transport of a sulphonamide antibiotic in soil systems, Toxicol Lett 131 (2002), pp. 19-28.

Breimer and Smilde, 1986 T. Breimer and K.W. Smilde, De effekten van organische mestdoseringen op de zware metaalgehalten in de bouwvoor van akkergronden, Themaboek vol. 7, PAGV, Lelystad, The Netherlands (1986).

Busheé et al., 1998 E.L. Busheé, D.R. Edwards and P.A. Moore, Quality of runoff from plots treated with municipal sludge and horse bedding, ASAE 41 (1998), pp. 1035-1041.

Campagnolo et al., 2002 E.R. Campagnolo, K.R. Johnson, A. Karpati, C.S. Rubin, D.W. Kolpin and M.T. Meyer et al., Antimicrobial residues in animal waste and water resources proximal to large-scale swine and poultry feeding operations, Sci Total Environ 299 (2002), pp. 89-95. 
Casey et al., 2003 F.X.M. Casey, G.L. Larsen, H. Hakk and J. Simunek, Fate and transport of 17ß-estradiol in soilwater systems, Environ Sci Technol 37 (2003), pp. 2400-2409.

Christian et al., 2003 T. Christian, R.J. Schneider, H.A. Farber, D. Skutlarek, M.T. Meyer and H.E. Goldbach, Determination of antibiotic residues in manure, soil, and surface waters, Acta Hydrochim Hydrobio/ 31 (2003), pp. 36-44.

Das et al., 2004 B.S. Das, L.S. Lee, P.S.C. Rao and R.P. Hultgren, Sorption and degradation of steroid hormones in soils during transport: column studies and model evaluation, Environ Sci Technol 38 (2004), pp. 1460-1470.

Dee, 1995 D.P. Dee, A pragmatic approach to model validation. In: D.R. Lynch and A.M. Davies, Editors, Quantitative skill assessment for coastal ocean models, American Geophysical Union, Washington DC, USA (1995) pp..

Deelstra et al., 2002 J. Deelstra, M. Bechmann and S.H. Kvaerno, SOIL and SOIL-NO at catchment scale-a case study for an agriculture-dominated catchment, Water Sci Technol 45 (2002), pp. 9-17.

De Greef and De Nijs, 1990 J. De Greef and A.C.M. De Nijs, Risk assessment of new chemical substances, Dilution factors of effluents in The Netherlands, RIVM, Bilthoven, The Netherlands (1990) report 670208001.

De Liguoro et al., 2003 M. De Liguoro, V. Cibin, F. Capolongo, B. Halling-Sørensen and C. Montesissa, Use of oxytetracycline and tylosin in intensive calf farming: evaluation of transfer to manure and soil, Chemosphere 52 (2003), pp. 203-212.

DG Enterprise, 2000 DG Enterprise, Pharmaceuticals in the European Union, Office for Official Publications of the European Communities, Luxembourg (2000) ISBN 92-828-9589-0.

Donham et al., 1988 K.J. Donham, J. Yeggy and R.R. Dague, Production rates of toxic gases from liquid swine manure: health implications for workers and animals in swine confinement buildings, Biol Wastes 24 (1988), pp. 161174.

Eghball, 1998 B. Eghball, Composting manure, Manure Matters 1 (1998), pp. 1-3.

EMEA, 1997 EMEA, Note for guidance: environmental risk assessment for veterinary medicinal products other than GMO-containing and immunological products, EMEA, London, UK (1997) EMEA/CVMP/055/96.

FOCUS, 1995 FOCUS, Leaching models and EU registration, EC DG Sanco, Brussels (1995) Document No. $4952 / \mathrm{VI} / 95$.

FOCUS, 2000 FOCUS, FOCUS groundwater scenarios in the EU plant protection product review process, EC DG Sanco, Brussels, Belgium (2000) Sanco/321/2000.

FOCUS, 2001 FOCUS. Surface water models and EU registration of plant protection products. Final report of the regulatory modelling working group on surface water models of FOCUS. Draft 21-12-2001. Brussels, Belgium: DG Sanco; 2001.

Frijters, 2000 C. Frijters, Onderzoek spoelwater Bloembollen; resultaten 1999, Zuiveringsschap Hollandse Eilanden en Waarden, Dordrecht (2000).

Gavalchin and Katz, 1994 J. Gavalchin and S.E. Katz, The persistence of fecal-borne antibiotics in soil, J AOAC Int 77 (1994), pp. 481-485.

Groen, 1997 K.P. Groen, Pesticide leaching in polders, Field and model studies on cracked clays and loamy sands, Ministry of Traffic and Public Works, Lelystad, the Netherlands (1997).

Halley et al., 1989 B.A. Halley, Th.A. Jacob and A.Y.H. Lu, The environmental impact of the use of ivermectin: environmental effects and fate, Chemosphere 18 (1989), pp. 1543-1563.

Hamscher et al., 2000 G. Hamscher, S. Sczesny, A. Abu-Quare and H. Höper, Stoffe mit pharmakologischer Wirkung einschliesslich hormonell aktiver Substanzen in der Umwelt: Nachweis von Tetrazyklinen in güllegedüngten Böden, Dtsch Tierärztl Wochenschr 107 (2000), pp. 332-334.

Hamscher et al., 2002 G. Hamscher, S. Sczesny, H. Höper and H. Nau, Determination of persistent tetracycline residues in soil fertilized with liquid manure by high-performance liquid chromatography with electrospray ionization tandem mass spectrometry, Anal Chem 74 (2002), pp. 1509-1518. 
Science of The Total Environment Volume 358, Issues 1-3 , 1 April 2006, Pages 121-136

Henschel et al., 1997 K.P. Henschel, A. Wenzel, M. Diedrich and A. Fliedner, Environmental hazard assessment of pharmaceuticals, Regul Toxicol Pharmacol 25 (1997), pp. 220-225.

Herd, 1995 R. Herd, Endectocidal drugs: ecological risks and counter-measures, Int J Parasitol 25 (1995), pp. 875885.

Hoeksma et al., 1987 P. Hoeksma, H.R. Poelma and A. Van Zadelhoff, Koude vergisting van mengmest; mogelijkheden voor praktijktoepassing, IMAG Wageningen, The Netherlands (1987).

Iglesias-Jimenez et al., 1997 E. Iglesias-Jimenez, E. Poveda, M.J. Sanchez-Martin and M. Sanchez-Camazano, Effect of the nature of exogenous organic matter on pesticide sorption by the soil, Arch Environ Contam Toxicol 33 (1997), pp. 117-124.

Ingerslev et al., 2001 F. Ingerslev, L. Toräng, M. Loke, B. Halling-Sørensen and N. Nyholm, Primary biodegradation of veterinary antibiotics in aerobic and anaerobic surface water simulation systems, Chemosphere 44 (2001), pp. 865-872.

Jenkins et al., 1997 M.B. Jenkins, D.D. Bowman, M.J. Walker and W.C. Ghiorse, Use of sentinel Cryptosporidium parvum oocysts to measure effects of passive manure storage on oocysts inactivation, 7 th International Coccidiosis Conference (1997) London.

Jorgensen et al., 1998 S.E. Jorgensen, H.C. Lützhoft and B. Halling-Sørensen, Development of a model for environmental risk assessment of growth promoters, Ecol Model 107 (1998), pp. 63-72.

Kamstra and Van der Heul, 1998 A. Kamstra and J.W. Van der Heul, Onderzoek naar behandeling van afvalwater van een palingkwekerij (tussenrapportage), RIVO-DLO, IJmuiden, The Netherlands (1998) C019/98.

Kay et al., 2004 P. Kay, P.A. Blackwell and A.B.A. Boxall, Fate of veterinary antibiotics in a macroporous tile drained clay soil, Environ Toxicol Chem 23 (2004), pp. 1136-1144.

Kelley et al., 1994 T.R. Kelley, O. Pancorbo, W. Merka and H. Barnhart, Fate of selected bacterial pathogens and indicators in fractionated poultry litter during storage, J Appl Poult Res 3 (1994), pp. 279-288.

Kelly et al., 2003 L.A. Kelly, M.A. Taylor and M.J.A. Wooldridge, Estimating the predicted environmental concentration of the residues of veterinary medicines: should uncertainty and variability be ignored?, Risk Anal $\mathbf{2 3}$ (2003), pp. 489-496.

Ketelaars and Van der Meer, 2000 J.J.M.H. Ketelaars and H.G. Van der Meer, Establishment of criteria for the assessment of the nitrogen content of animal manures. Final Report to ERM, Plant Research International, Wageningen (2000).

Kühne et al., 2000 M. Kühne, D. Ihnen, G. Möller and O. Aghte, Stability of tetracycline in water and liquid manure, $J$ Vet Med, A 47 (2000), pp. 379-384.

Lalumera et al., 2004 G.M. Lalumera, D. Calamari, P. Galli, S. Castiglioni, G. Crosa and R. Fanelli, Preliminary investigation on the environmental occurrence and effects of antibiotics used in aquaculture in Italy, Chemosphere 54 (2004), pp. 661-668.

Leonard et al., 1979 R.A. Leonard, G.W. Langdale and W.G. Fleming, Herbicide runoff from upland peidmont watersheds_data and implications for modeling pesticide transport, J Environ Qual 8 (1979), pp. 223-229.

Luiten, 2002 E.E.M. Luiten, Controverses rond kweek van vis in Nederland?, Stichting Toekomstbeeld der Techniek, Den Haag (2002) http://www.minocw.nl/cos/doc/2002/oceanfarm visteelt.PDF.

Lumaret and Errouissi, $2002 \mathrm{~J}$. Lumaret and F. Errouissi, Use of anthelmintics in herbivores and evaluation of risks for the non target fauna of pastures, Vet Res 33 (2002), pp. 547-562.

Lumaret et al., 1993 J. Lumaret, E. Galante, C. Lumbreras, J. Mena, M. Bertrand and J.L. Bernal et al., Field effects of ivermectin residues on dung beetles, J Appl Ecol 30 (1993), pp. 428-436.

MacKay et al., 1986 D. MacKay, S. Paterson and W. Schroeder, Model describing the rates of transfer processes of organic chemicals between atmosphere and water, Environ Sci Technol 20 (1986), pp. 810-816.

MARAN, 2002 MARAN, Monitoring of antimicrobial resistance and antibiotic usage in animals in The Netherlands in 2002, VANTURES, The Hague (2002). 
McLachlan et al., 2002 M.S. McLachlan, G. Czub and F. Wania, The influence of vertical sorbed phase transport on the fate of organic chemicals in surface soils, Environ Sci Technol 36 (2002), pp. 4860-4867.

Menzi, 2002 H. Menzi, Manure management in Europe: results of a recent survey, Strbeské Pleso, Slovak Republic: Proceedings of the 10th International Conference of the RAMIRAN Network (2002).

Montfoort et al., 1996 J.A. Montfoort, P. Van der Poel and R. Luttik, The use of disinfectants in livestock farming, National Institute for Public Health and the Environment, Bilthoven, The Netherlands (1996) RIVM Report 679102033

Montforts, 1999 M.H.M.M. Montforts, Environmental risk assessment for veterinary medicinal products: 1. Other than GMO-containing and immunological products, National Institute for Public Health and the Environment (RIVM), Bilthoven, The Netherlands (1999) RIVM report 601300001.

Montforts, 2003 M.H.M.M. Montforts, Environmental risk assessment for veterinary medicinal products: 1. Nonimmunological drug substances. Second update, National Institute for Public Health and the Environment (RIVM), Bilthoven, The Netherlands (2003) RIVM report 320202001/2003.

Montforts et al., 1999 M.H.M.M. Montforts, D.F. Kalf, P.L.A. Van Vlaardingen and J.B.H.J. Linders, The exposure assessment for veterinary medicinal products, Sci Total Environ 225 (1999), pp. 119-133.

Montforts et al., 2004 M.H.M.M. Montforts, H.F.M.W. Van Rijswick and H.A. Udo de Haes, Legal constraints in EU product labelling to mitigate the environmental risk of veterinary medicines at use, Regul Toxicol Pharmacol 40 (2004), pp. 327-335.

Moreira, 2001 Moreira V. Manure handling and storage effects on nitrogen losses of dairy farms http://dfrc.wisc.edu/powell/, 2001. Date of access 2003.

Morillo et al., 2002 E. Morillo, C. Maqueda, R. Reinoso and T. Undabeytia, Effect of two organic amendments on norflurazon retention and release by soils of different characteristics, Environ Sci Technol 36 (2002), pp. 4319-4325.

Nessel et al., 1989 R.J. Nessel, D.H. Wallace, T.A. Wehner, W.E. Tait and L. Gomez, Environmental fate of ivermectin in a cattle feedlot, Chemosphere 7-8 (1989), pp. 1531-1541.

Nichols et al., 1997 D.J. Nichols, T.C. Daniel, P.A. Moore, D.R. Edwards and D.H. Pote, Runoff of estrogen hormone 17ß-estradiol from poultry litter applied to pasture, J Environ Qual 26 (1997), pp. 1002-1006.

Novem, 1991 Novem. Commersialisering van koude vergisting van varkensdrijfmest onder stal met behulp van kapjessysteem. NOVEM/RIVM/Haskoning. 1991;No. 9134:Nijmegen, The Netherlands.

Nowara et al., 1997 A. Nowara, J. Burhenne and M. Spiteller, Binding of fluoroquinolone carboxylic acid derivatives to clay minerals, J Agric Food Chem 45 (1997), pp. 1459-1463.

Pablos et al., 1998 MaV. Pablos, C. Ramos, G. Carbonell and J.V. Tarazona, Evaluación del riego ambiental de fármacos de uso veterinario: Desarrollo de escenarios para sistemas ganaderos intensivos y extensivos, Cuad Investig Biol 20 (1998), pp. 507-510.

Panter et al., 1999 G.H. Panter, R.S. Thompson, N. Beresford and J.P. Sumpter, Transformation of a nonoestrogenic steroid metabolite to an oestrogenically active substance by minimal bacterial activity, Chemosphere $\mathbf{3 8}$ (1999), pp. 3579-3596.

Pau Vall and Vidal, 2001 Pau Vall M, Vidal C. Nitrogen in agriculture. 2001. Date of access 2002.

Pitts et al., 1998 C.W. Pitts, P.C. Tobin and B. Weidenboerner, In-house composting to reduce larval house fly, Musca domestica L., populations, J Appl Poult Res 7 (1998), pp. 180-188.

Polyakov and Lal, 2004 V. Polyakov and R. Lal, Modeling soil organic matter dynamics as affected by soil water erosion, Environ Int 30 (2004), pp. 547-556.

Provolo and Riva, 2002 G. Provolo and E. Riva, Manure management practices in Lombardy (Italy). In: J. Venglovský and G. Gréserová, Editors, Proceedings of the 10th International Conference of the RAMIRAN Network, Strbeské Pleso, Slovak Republic (2002).

Qiang, 1999 Z. Qiang, In-barn evaluations of manure pit additives for odour reduction, Manitoba Agriculture and Food, Canada (1999) ARDI Project \# 98-087. 
Rabølle and Spliid, 2000 M. Rabølle and N.H. Spliid, Sorption and mobility of metronidazole, olaquindox and oxytetracycline and tylosine in soil, Chemosphere 40 (2000), pp. 715-722.

Ramazza et al., 1996 V. Ramazza, M. Zucchi, A. Lanzoni and C. Bianchi, Presence of oxytetracycline in pig farming after high doses and longer administration times in comparison to the suggested ones, Proc. Euro Residue Conference III vol. 2, Veldhoven, The Netherlands (1996), pp. 814-818.

Richard et al., 1998 T. Richard, J. Harmon, M. Honeyman and J. Creswell, Hoop structure bedding use, labor, bedding pack temperature, manure nutrient content, and nitrogen leaching potential, lowa State University (1998) ASL-R1499.

Schiffer et al., 2001 B. Schiffer, A. Daxenberger, K. Meyer and H.H.D. Meyer, The fate of trenbolone acetate and melengestrol acetate after application as growth promoters in cattle: environmental studies, Environ Health Perspect 109 (2001), pp. 1145-1151.

Schlüsener et al., 2003 M.P. Schlüsener, K. Bester and M. Spiteller, Determination of antibiotics such as macrolides, ionophores and tiamulin in liquid manure by HPLC-MS/MS, Anal Bioanal Chem 375 (2003), pp. 942-947.

Schowanek and Webb, 2002 D. Schowanek and S. Webb, Exposure simulation for pharmaceuticals in European surface waters with GREAT-ER, Toxicol Lett 131 (2002), pp. 39-50.

Schrap et al., 2003 S.M. Schrap, G.B.J. Rijs, M.A. Beek, J.F.N. Maaskant, J. Staeb and G. Stroomberg et al., Humane en veterinaire geneesmiddelen in Nederlands oppervlaktewater en afvalwater, RIZA, Lelystad (2003) RIZA report 2003.023.

Short et al., 1987 C.R. Short, S.A. Barker, L.C. Hsieh, S.-P. Ou, T. McDowell and L.E. Davis et al., Disposition of fenbendazole in cattle, Am. J. Vet. Res. 48 (1987), pp. 958-961.

Smith et al., 2001 K.A. Smith, D.R. Jackson and T.J. Pepper, Nutrient losses by surface run-off following the application of organic manures to arable land: 1. Nitrogen, Environmental Pollution 112 (2001), pp. 41-51.

Soulides et al., 1962 D.A. Soulides, L.A. Pinck and F.E. Allison, Antibiotics in soils: V. Stability and release of soil adsorbed antibiotics, Soil Sci 94 (1962), pp. 239-244.

Southwick et al., 2003 L.M. Southwick, B.C. Grigg, J.L. Fouss and T.S. Kornecki, Atrazine and metolachlor in surface runoff under typical rainfall conditions in southern Louisiana, J Agric Food Chem 51 (2003), pp. 5355-5361.

Spaepen et al., 1997 K.R.I. Spaepen, L.J.J. Van Leemput, P.G. Wislocki and C. Verschueren, A uniform procedure to estimate the predicted environmental concentration of the residues of veterinary medicines in soil, Environ Toxicol Chem 16 (1997), pp. 1977-1982.

Strong et al., 1996 L. Strong, R. Wall, A. Woolford and D. Djeddour, The effect of faecally excreted ivermectin and fenbendazole on the insect colonisation of cattle dung following the oral administration of sustained-release boluses, Vet Parasitol 62 (1996), pp. 253-266.

Tarazona et al., 2003 Tarazona JV, Calow P, Montforts MHMM, Herrchen M, Luttik R, Wester P, et al. Report on the ecological risk assessment of chemicals. Appendix $5 \mathrm{in}$ : SSC, The future of risk assessment in the European Union. The second report on the harmonisation of risk assessment procedures. Brussels: Scientific Steering Committee, Health and Consumer Protection Directorate-General, European Union., 2003.

Tijmensen et al., 2002 Tijmensen MJA, Van den Broek RCA, Wasser R, Kool A, De Mol RM, Hilhorst MA. Mestvergisting op boerderijschaal in bestaande opslagsystemen. ECOFYS, CLM, IMAG, The Netherlands; 2002. Rapport 373002-0230.

Van Beersum, 1988 C. Van Beersum, De bezinkput, een saneringsmethode voor champignonteelt-afvalwater?, RIZA, Lelystad (1988) RIZA report 88.021.

Van der Poel and Bakker, 2002 P. Van der Poel and J. Bakker, Emission Scenario Document for Biocides. Emission scenarios for all 23 product types of the Biocidal Products Directive (EU Directive 98/8/EC), RIVM, Bilthoven, The Netherlands (2002) RIVM report 601450009.

Van Staalduinen et al., 2001 L.C. Van Staalduinen, H. Van Zeijts, M.W. Hoogeveen, H.H. Luesink, T.C. Van Leeuwen and $\mathrm{H}$. Prins et al., Het landelijk mestoverschot 2003. Methodiek en berekening, Reeks Milieuplanbureau vol. 15, LEI, The Hague, The Netherlands (2001) 
Science of The Total Environment Volume 358, Issues 1-3, 1 April 2006, Pages 121-136

Vega et al., 2001 M.M. Vega, G. Carbonell, M.V. Pablos, C. Ramos, C. Fernández and J.A. Ortiz et al., Evaluación ambiental de residuos ;procinos y gestión agrícola de purines mediante el modelo informático EGPE, Invest Agric Prod Sanid Anim 16 (2001), pp. 165-180.

Vej-Hansen et al., 1978 B. Vej-Hansen, H. Bundgaard and B. Kreilgård, Kinetics of degradation of oxytetracycline in aqueous solution, Arch Pharm Chemi Sci Ed 6 (1978), pp. 951-963.

VICH, $2000 \mathrm{VICH}$, Environmental impact assessment (EIAs) for veterinary medicinal products (VMPs): Phase I, CVMP/VICH, London (2000) CVMP/VICH/592/98-final.

VICH, $2003 \mathrm{VICH}$, Environmental impact assessment (EIAs) for veterinary medicinal products (VMPs): Phase II. Draft Guidance, CVMP/VICH, London (2003) CVMP/VICH/790/03-Consultation.

Vischetti et al., 1997 C. Vischetti, M. Businelli, M. Marini, E. Capri, M. Trevisan and A.A.M. Del Re et al., Characterisation of spatial variability structure in three separate field trials on pesticide dissipation, Pestic Sci $\mathbf{5 0}$ (1997), pp. 175-182.

Wagemaker, $1993 \mathrm{~F}$. Wagemaker, Aangepast voorstel risiko-evaluatie voor bestrijdingsmiddelen die gebruikt worden in de champignonteelt, RIZA, Lelystad (1993).

Walker, 1997 F.R. Walker, A fate and transport model of Cryptosporidium in the New York City water supply watersheds, Cornell University, Ithaca, USA (1997).

Walker and Stedinger, 1999 F.R. Walker and J.R. Stedinger, Fate and transport model of Cryptosporidium, J Environ Eng 125 (1999), pp. 325-333.

Walker et al., 1998 M.J. Walker, C.D. Montemagno and M.B. Jenkins, Source water assessment and nonpoint sources of acutely toxic contaminants: a review of research related to survival and transport of Cryptosporidium parvum, Water Resour Res 34 (1998), pp. 3383-3392.

Winckler and Grafe, 2001a Winckler C, Grafe A. Charakterisierung und Verwertung van Abfällen aus der Massentierhaltung unter Berücksichtigung verschiedener Böden. Stoffeintrag in Böden durch Tierarzneimittel und pharmakologisch wirksame Futterzusatzstoffe unter besonderer Berücksichtigung von Tetrazyklinen. Berlin, Germany: UBA, 2001a. UBA report 29733911-UBA-FB 000074.

Winckler and Grafe, 2001b C. Winckler and A. Grafe, Transfer of veterinary drugs and pharmacologically-active feed additives into soil with special consideration of tetracyclines-executive summary, J Soils Sediments 1 (2001), pp. $58-62$.

Winckler and Grafe, 2001c C. Winckler and A. Grafe, Use of veterinary drugs in intensive animal production: evidence for persistence of tetracycline in pig slurry, J Soils Sediments 1 (2001), pp. 66-70.

WRc-NSF, 2000 WRc-NSF, The development of a model for estimating the environmental concentration (PECs) of veterinary medicines in soil following manure spreading, MAFF, London, UK (2000) VM0295.

WRc-NSF, 2001 WRc-NSF. VetPec. Veterinary Medicines Directorate, UK; 2001.

Zilles et al., 2005 J. Zilles, T. Shimada, A. Jindal, M. Robert and L. Raskin, Presence of macrolide-lincosamidestreptogramin b and tetracycline antimicrobials in swine waste treatment processes and amended soil, Water Environ Res 77 (2005), pp. 57-62. 